\title{
Care Bundle for Medical Device-Related Pressure Injuries in Covid-19 times
}

\section{Daniela Soldera, Juliana Balbinot Reis Girondi, Karina Silveira de Almeida Hammerschimdt Cilene Fernandes Soares, Lúcia Nazareth Amante, Aline de Oliveira Ramalho Bettina Heidenreich Silva, Luciara Fabiane Sebold}

\author{
Rua Emir Rosa, 593 Florianópolis, SC, Brazil. \\ *Corresponding Author: Bettina Heidenreich Silva, Rua Emir Rosa, 593 Florianópolis, SC, Brazil.
}

Abstract

Objective: To validate the content of the Nursing Care Bundle for the prevention, diagnosis and treatment of Medical device-related Pressure Injuries.

Method: Methodological study, with a quantitative approach, conducted in May and June 2019, with a sample of 20 nurses specialized in stomatherapy, using an electronic form, consisting of prevention actions, nursing diagnoses and treatments for Medical device-related Pressure Injuries. For data analysis, the content validity index $(\geq 0.8)$ was used.

Results: The Bundle was validated in its final version with care aimed at prevention, nursing diagnosis and treatment of Medical device-related Pressure Injuries, with CVI of 0.93.

Conclusions: The validated Bundle contributes to reducing the occurrence of Medical device-related Pressure Injuries by qualifying the nursing care provided, envisioning patient safety in Covid-19 times.

Keywords: Nursing; Pressure injury; Equipment and supplies; Coronavirus; Nursing care.

\section{INTRODUCTION}

The World Health Organization (WHO), in mid-March 2020, declared a worldwide pandemic alert and mobilization, due to the high number of infection cases caused by the coronavirus COVID-19 (1).

In Brazil, the pandemic began in late February, and the number of infected individuals has been increasing daily, as it is a virus with a high potential for transmission (2).

The patients affected by COVID-19 have variable clinical symptoms, with some individuals with asymptomatic infection, going from mild illness with signs and nonspecific symptoms of acute respiratory illness to severe or fatal illness characterized by pneumonia, with severe respiratory impairment, which may result in hospitalization in intensive care units, orotracheal intubation, use of vasoactive drugs and septic shock (3).
The elderly population and individuals with some chronic disease are vulnerable to presenting symptoms more severely, as aging and illness tend to decrease immunity against infections in general (4).

In view of the severity of the symptoms triggered by COVID-19, many patients require intensive care, where the use of medical devices is essential for maintaining life. However, some critical patients have significant pressure and respiratory lability, where minimal movements can result in clinical decompensation (3).

One of the approaches adopted for the treatment of acute respiratory distress syndrome is the prone position, which must be applied early (first 48 hours), once pronated, the patient must be kept for at least 16 hours in this position, triggering the risk of develop Pressure Injuries (PI), especially those related to medical devices (5).

In the face of the pandemic, the risk of developing Medical device-related Pressure Injuries (MDRPI) is 
a growing problem, also associated with the fact that the populationmost affected by the virus are elderly and with associated comorbidities, increasing the risk of developing skin lesions (3-4).

The National Pressure Injury Advisory Panel (NPIAP) describes that the damage to the underlying skin occurs over bony prominence or is related to a medical device or other type of device. MDRPI results from the use of medical devices, designed and applied for diagnostic or therapeutic purposes, where PI generally maintains the pattern or shape of the device. Therefore, these injuries must be classified using the staging system (6).

The nurse has a fundamental role with regard to holistic care, however many MDRPI are iatrogenic, due to the fixation of the device making it difficult to inspect the skin or mucosa. Thus, evaluation is essential to implement effective preventive measures and for this to happen, it is essential that this professional has technical-scientific knowledge based on evidence about this disease (7).

As a prevention and care strategy, Bundles are instruments that, through care management, enable safety and quality of care based on current scientific knowledge, especially when anchored in levels of evidence. In addition, it recommends that all actions should be observed, otherwise the same results are not obtained (7).

\section{OBJECTIVE}

Validate a Nursing Care Bundle for prevention, diagnosis and treatment of MDRPI during hospitalization.

\section{METHODS}

\section{Ethical Aspects}

The study was approved by the Human Research Ethics Committee at the Federal University of Santa Catarina (UFSC).

\section{Design, Sample and Inclusion and Exclusion Criteria}

This is a methodological study with the purpose of validating a bundle of nursing care for the prevention, diagnosis and treatment of MDRPI.

The methodological trajectory of the study followed the validation of the instrument by a panel of experts and agreement between the expert judges in the area of stomatherapy to define the representativeness of the measured construct.

To build the initial sample of experts, the Snowball technique was used, where the seeds help the researcher to establish contacts. Thus, it is requested that the professionals indicated by the seeds indicate new contacts with the desired characteristics, from their personal network and so on (8).

For validation of the instrument, experts on the theme were invited to participate, according to the inclusion criteria: nurses who develop assistance, teaching and / or research activities with the title of Stomatherapist certified by the Brazilian Association of Stomatherapy (SOBEST). As for the exclusion criterion, it consisted of not respecting the 10-day deadline for returning the completed data collection instrument.

134 nurses were contacted by e-mail, through an invitation letter in which the guidelines and justifications for this study and the importance of participation as a specialist were elucidated. After acceptance, the link was sent to access the Consent Form, being essential the signature to access the validation instrument. Twenty nurses participated in the validation of the instrument.

\section{Study Protocol}

The validation stage took place in the period from April to May 2019. The validation instrument was prepared via an online form, on Google Docs $₫$, a multifunctional tool shared via real-time email through the generated link, allowing the use of electronic spreadsheets. To assess the agreement of the opinions, the Likert scale was used to record the evaluation containing the scores 1 (disagree), 2 (partially disagree), 3 (partially agree) and 4 (agree). Were assessed for agreement, relevance and accuracy of the wording, in addition to a field of open responses to suggestions, observations, opinions and comments from experts (9).

The form was made available to the evaluating judges through two rounds of validation, developed according to the recommendation of the Delphi technique. These steps are in line with the literature, which points out that for the application of the referred technique, the researcher must prepare an objective form, structured or not, exploring the points that he wants to know the consensus of the specialists and send to them. The 
Care Bundle for Medical Device-Related Pressure Injuries in Covid-19 times

form circulates through the group of experts to reach consensus.

For the statistical treatment in this phase, the categories were considered: completely adequate and adequate for those who reached a consensus $\geq$ $80 \%(0.8)$, with this agreement index based on other validation studies. The consensus of $80 \%(0.8)$ or more was considered valid between the evaluations of the judges, the values below $80 \%$ were adjusted, based on the experts' suggestions, being forwarded for a new evaluation $(10,11)$.

The analysis of the second round generated reformulation and refinement of the content of the initial instrument. The experts' agreement regarding the representativeness of the items in relation to the content covered was measured using the content validity index (CVI), calculated by the number of

Table1. Trial of experts for Bundle in the first and second round of the validation process. Florianópolis, SC - Brazil, $2020(n=20)$

\begin{tabular}{|l|l|l|l|l|}
\hline & CVI *\% & A*\% & P*\% & AW*\% \\
\hline Nursing Diagnosis: Pain ${ }^{(25)}$ & & & & \\
\hline $\begin{array}{l}\text { Pain under medical device is a predictive sign of Medical device-related } \\
\text { Pressure Injuries }\end{array}$ & 95 & 95 & 90 & 100 \\
\hline Sudden or slow onset pain under and around the medical device & 95 & 95 & 100 & 100 \\
\hline Mild to severe pain under and around the medical device & 95 & 95 & 100 & 100 \\
\hline $\begin{array}{l}\text { Regular skin assessment after complaints of pain and discomfort reported by } \\
\text { the patient and / or companion, especially in patients at higher risk (advanced } \\
\text { age, malnutrition, edema) }\end{array}$ & 95 & 95 & 90 & 100 \\
\hline Nursing Diagnosis: Pressure Injury (25) & & & & \\
\hline $\begin{array}{l}\text { Injury located on the skin and / or underlying tissue usually on a bony } \\
\text { prominence, resulting from pressure and shear or related to a medical device, } \\
\text { categorized in stages }\end{array}$ & 100 & 100 & 100 & 100 \\
\hline Pressure Injury stage 1: Skin intact with erythema that does not whiten & 95 & 95 & 100 & 100 \\
\hline Stage 2 Pressure Injury: Partial thickness loss of skin with exposure of the dermis & 94 & 94 & 100 & 100 \\
\hline Stage 3 Pressure Injury: Loss of full thickness skin & 100 & 100 & 100 & 100 \\
\hline Stage 4 Pressure Injury: Loss of full thickness skin and non-visible tissue loss & 0,94 & 94 & 100 & 100 \\
\hline $\begin{array}{l}\text { Deep Tissue Injury: dark red, brown or purple discolouration, persistent and } \\
\text { non-whitening }\end{array}$ & 100 & 100 & 100 & 100 \\
\hline Nursing Diagnosis: Impaired skin integrity (25) & & 100 & 100 & 100 \\
\hline $\begin{array}{l}\text { Defined as dermis and altered epidermis, such as: alteration in the integrity of } \\
\text { the skin, localized area hot to the touch, acute pain, foreign matter perforating } \\
\text { the skin, redness }\end{array}$ & 100 & & 100 \\
\hline
\end{tabular}

Open Journal of Geriatrics V3 . I2 . 2020

evaluators in agreement with the item by the total number of evaluators (10).

\section{RESULTS}

The sample consisted of 20 evaluators, predominantly female (85\%), mostly qualified as masters (50\%), followed by doctors (25\%), specialists (20\%) and postdoctorate (5\%). Regarding the length of experience in the profession, most have worked for more than 20 years (35\%) with $30 \%$ working for 11 to 15 years and $20 \%$ between five to ten years. As for the area, the highest concentration is in the hospital environment (45\%), followed by activities related specifically to stomatherapy (45\%) and the minority $(10 \%)$ in hospital level concurrent with Primary Health Care. Finally, $40 \%$ of participants exercise teaching activity at a higher level, $35 \%$ in post-graduation and $20 \%$ do not exercise professors. 
Care Bundle for Medical Device-Related Pressure Injuries in Covid-19 times

\begin{tabular}{|c|c|c|c|c|}
\hline Hyperemia under and around the medical device & 95 & 95 & 100 & 100 \\
\hline Skin macerated at the insertion site of the medical device & 95 & 95 & 100 & 100 \\
\hline Altered microclimate under and around the medical device & 95 & 95 & 100 & 100 \\
\hline Medical device inserted improperly, damaging tissue & 95 & 95 & 90 & 100 \\
\hline Localized edema & 95 & 95 & 100 & 100 \\
\hline \multicolumn{5}{|l|}{ Prevention and treatment } \\
\hline $\begin{array}{l}\text { Inspect the skin under and around the medical device more than } 2 \mathrm{x} \text { a day in } \\
\text { people with specific conditions (risk of edema / generalized edema) }\end{array}$ & 80 & 80 & 100 & 100 \\
\hline Choose the right sized device for each patient & 100 & 100 & 100 & 100 \\
\hline Choose medical device with flexible and soft material & 100 & 100 & 100 & 100 \\
\hline $\begin{array}{l}\text { Develop an individualized skin assessment plan under and around the medical } \\
\text { device in cases of edema or risk of edema }\end{array}$ & 95 & 95 & 100 & 100 \\
\hline Loosen the fixings of the medical device whenever necessary & 80 & 80 & 90 & 100 \\
\hline Keep skin clean and dry under and around the medical device & 100 & 100 & 100 & 100 \\
\hline Avoid insertion of medical device in areas with pre-existing skin lesions & 95 & 95 & 100 & 100 \\
\hline Apply monolayer occlusive dressing depending on the situation & 84 & 84 & 90 & 100 \\
\hline Apply occlusive dressings with multiple layers depending on location and area & 89 & 89 & 95 & 100 \\
\hline Apply fixations that allow visualization of the skin & 90 & 90 & 100 & 100 \\
\hline $\begin{array}{l}\text { Apply transparent films that allow visualization of the insertion site of the } \\
\text { medical device as far as possible }\end{array}$ & 100 & 100 & 100 & 100 \\
\hline Perform dressing changes when moisture is present & 100 & 100 & 100 & 100 \\
\hline Apply thin hydrocolloid to avoid pressure and shear & 80 & 80 & 100 & 100 \\
\hline $\begin{array}{l}\text { Apply specific devices as a preventive support for Medical device-related } \\
\text { Pressure Injuries }\end{array}$ & 85 & 85 & 90 & 90 \\
\hline Avoid overlapping dressings & 95 & 95 & 100 & 100 \\
\hline Choose dressings according to anatomical location & 100 & 100 & 100 & 100 \\
\hline Choose dressings that allow ease of application and removal & 100 & 100 & 100 & 100 \\
\hline Apply foam dressings to prevent pressure and shear and moisture absorption & 90 & 90 & 100 & 100 \\
\hline $\begin{array}{l}\text { Apply foams to absorb peristomal moisture (tracheostomy and gastrostomy) } \\
\text { and under non-invasive ventilation masks }\end{array}$ & 90 & 90 & 100 & 100 \\
\hline Apply foam dressings to maintain the microclimate & 95 & 95 & 100 & 100 \\
\hline Apply foam dressings as they distribute pressure better & 95 & 95 & 100 & 100 \\
\hline Apply foam dressing under tracheostomy cannula & 95 & 95 & 100 & 100 \\
\hline Apply skin protector to each dressing change & 80 & 80 & 100 & 100 \\
\hline Apply barrier-forming tissue to peristomal area of tracheostomy & 89 & 89 & 100 & 100 \\
\hline
\end{tabular}

Note: * CVI: content validity index, ${ }^{*}$ A: agreement, $*$ P: pertinence, ${ }^{*}$ AW: accuracy of writing 
Care Bundle for Medical Device-Related Pressure Injuries in Covid-19 times

Table2. Bundle for the prevention of Medical device-related Pressure Injuries. Florianópolis, SC, Brazil, 2019.

\begin{tabular}{|l|l|}
\hline Preventive Care & Detailing of Care \\
\hline Daily skin inspection & $\begin{array}{l}\text { Inspect the skin under and around the medical device more than once a } \\
\text { day; establish an individualized skin assessment plan under and around the } \\
\text { medical device in cases of edema or risk of edema. }\end{array}$ \\
\hline $\begin{array}{l}\text { Choice and fixation of the } \\
\text { medical device }\end{array}$ & $\begin{array}{l}\text { Choose a medical device made of flexible and soft material with the } \\
\text { appropriate size for each patient, refixing the device whenever necessary. }\end{array}$ \\
\hline Repositioning the medical & $\begin{array}{l}\text { Reposition the medical device at least twice a day; } \\
\text { Establish an individualized skin assessment plan under and around the } \\
\text { medical device in cases of edema or risk of edema. }\end{array}$ \\
\hline Skin care & $\begin{array}{l}\text { Keep the skin under and around the medical device always clean and dry; } \\
\text { Avoid inserting medical devices in areas with pre-existing skin lesions. }\end{array}$ \\
\hline the medical device & $\begin{array}{l}\text { Apply skin protector to each dressing change and in the peristomal area of } \\
\text { the tracheostomy (in spray, cream or tissue); } \\
\text { Choice of prophylactic coverage according to the device, insertion site and } \\
\text { clinical aspects of the patient; } \\
\text { Consider: } \\
\text { - Use fine hydrocolloid to protect the friction and shear: pay attention to areas of } \\
\text { excess moisture, due to the risk of maceration and detachment of the cover; } \\
\text { - Use foam dressings as they distribute pressure better, for protection from } \\
\text { friction and shear and moisture absorption. }\end{array}$ \\
\hline
\end{tabular}

Table3. Bundle for Nursing Diagnosis of Medical device-related Pressure Injuries. Florianópolis, SC, Brazil, 2019.

\begin{tabular}{|c|c|c|}
\hline Nursing Diagnoses & Detailing of care & Defining characteristics \\
\hline Pain & $\begin{array}{l}\text { - Identify pain located in the region of a } \\
\text { medical device. } \\
\text { - Assess pain intensity using predictive } \\
\text { scales: Visual analog or Behavior Pain } \\
\text { Scale in sedated patients using me- } \\
\text { chanical ventilation. } \\
\text { - Pay attention to patients with a po- } \\
\text { tential risk of Medical device-related } \\
\text { Pressure Injuries for complaints of } \\
\text { pain and discomfort. } \\
\text { Promote pain control. }\end{array}$ & $\begin{array}{l}\text {-Pain located in the region of the medical } \\
\text { device is a predictive sign of Medical device- } \\
\text { related Pressure Injuries. } \\
\text { - Sudden or slow onset pain under and around } \\
\text { the medical device. } \\
\text { - Mild to severe pain under and around the } \\
\text { medical device. } \\
\text { - Regular skin assessment after complaints of } \\
\text { pain and discomfort referred by the patient and } \\
\text { / or companion, especially in patients at higher } \\
\text { risk (advanced age, malnutrition, edema). }\end{array}$ \\
\hline $\begin{array}{l}\text { Impaired skin in- } \\
\text { tegrity }\end{array}$ & $\begin{array}{l}\text { Assess hyperemia around the medi- } \\
\text { cal device. } \\
\text { Identify skin maceration at the inser- } \\
\text { tion site of the medical device. } \\
\text { Assess for moisture and heat under } \\
\text { and around the medical device. } \\
\text { Certify as to the insertion mode and- } \\
\text { correct positioning of the medical de- } \\
\text { vice to avoid injury to the skin. } \\
\text { Assess for the presence of edema un- } \\
\text { der and around the medical device. }\end{array}$ & $\begin{array}{l}\text {-Dermis and epidermis altered, as: alteration } \\
\text { in the integrity of the skin, localized area hot } \\
\text { to the touch, acute pain, foreign matter perfo- } \\
\text { rating the skin, redness. } \\
\text { - Hyperemia under around the medical device. } \\
\text { - Skin macerated at the insertion point of the } \\
\text { medical device. } \\
\text { - Microclimate changed under and around the } \\
\text { medical device. } \\
\text { - Medical device inserted improperly, dama- } \\
\text { ging the tissue. } \\
\text { - Localized edema. }\end{array}$ \\
\hline
\end{tabular}




\begin{tabular}{|c|c|c|}
\hline Pressure Injury & $\begin{array}{l}\text { Staging the Medical device-related } \\
\text { Pressure Injuries in accordance with } \\
\text { the National Pressure Injury Advi- } \\
\text { sory Panel's staging system. } \\
\text { Evolve the characteristics of the le- } \\
\text { sion in detail. }\end{array}$ & $\begin{array}{l}\text {-Injury located on the skin and / or underlying } \\
\text { tissue usually on a bony prominence, resulting } \\
\text { from Medical device-related Pressure Injuries } \\
\text { or other, being categorized into stages: } \\
\text { - Pressure Injury stage 1: Skin intact with } \\
\text { erythema that does not whiten; } \\
\text { - Pressure Injury stage 2: Loss of the skin in } \\
\text { its partial thickness with exposure of the der- } \\
\text { mis; } \\
\text { - Pressure Injury stage 3: Loss of skin in its } \\
\text { full thickness; } \\
\text { - Pressure Injury stage 4: Loss of skin in its } \\
\text { full thickness and non-visible tissue loss; } \\
\text { - Deep Tissue Injury: dark red, brown or pur- } \\
\text { ple discolouration, persistent and not white- } \\
\text { ning. } \\
\text { Pressure injury on mucous membrane. }\end{array}$ \\
\hline
\end{tabular}

Table4. Bundle for the Treatment of Medical device-related Pressure Injuries. Florianópolis, SC, Brazil, 2019.

\begin{tabular}{|l|l|}
\hline Treatment & Detailing Care \\
\hline Microclimate and exudate control & $\begin{array}{l}\text { Use polyurethane foam dressings as they distribute pressure better, } \\
\text { protection against friction and shear, better absorption of moisture } \\
\text { and maintenance of the skin's microclimate. } \\
\text { Consider: } \\
\text { Apply in peristomal sites (tracheostomy and gastrostomy), under } \\
\text { non-invasive ventilation masks and tracheostomy cannulas. }\end{array}$ \\
\hline Dressing change & $\begin{array}{l}\text { Select coverings that allow easy application and removal, according } \\
\text { to the anatomical location and clinical aspects of the patient, repla- } \\
\text { cing when there is excess moisture and avoiding overlapping of dres- } \\
\text { sings. }\end{array}$ \\
\hline $\begin{array}{l}\text { Daily skin assessment, follow-up } \\
\text { and monitoring of the lesion }\end{array}$ & $\begin{array}{l}\text { Individualized plan for daily skin assessment under and around the } \\
\text { medical device. } \\
\text { Consider in the case of pressure injury related to medical device: } \\
\text { Describe in medical records as to: staging, characteristics of the le- } \\
\text { sion, presence of exudate, edema, maceration and hyperemia of the } \\
\text { skin; as well as the applied conduct and implemented treatments. }\end{array}$ \\
\hline
\end{tabular}

\section{DiscusSION}

The bundle of care for prevention, diagnoses and nursing treatment was validated in relation to the criteria of agreement, relevance and accuracy of the writing, since the final CVI 0.93, respectively, reaching the values indicated in the literature (10).

Studies reveal that MDRPI are frequent mainly in the elderly, due to capillary fragility, among other changes resulting from aging, causing the development of skin lesions. In addition, the elderly are more vulnerable to infections caused by COVID-19 due to low immunity caused by aging $(4,12)$.

Elderly patients who are in critical condition in Intensive Care Units (ICUs) caused by COVID-19, need medical devices for therapeutic applicability, making them more susceptible to MDRPI, so that the devices with the greatest potential for injury are observed are respiratory, food, nasogastric tubes, oximeters and adhesives. Corroborating that, MDRPI may be related to the fact that professionals direct the focus on pathology and other organs than skin care, therefore 
the importance of implementing the Care Bundle for standardization of nursing care is emphasized (12).

In this sense, the nurse must use instruments to guide nursing care regarding the choice and fixation of the medical device, it must be of flexible material and of adequate size for each patient, taking care to loosen its fixations whenever necessary and provided that the patient's clinical condition permits $(13,14,15)$. In addition, it must be repositioned twice a day $(15,16,17)$.

With regard to preventive care regarding MDRPI, daily skin inspection should be performed more than once a day, in addition to carrying out a plan for its evaluation under and around the medical device in patients with specific conditions, exemplifying those with swelling or at risk of edema, anasarca or presence of fluids around the medical device $(19,20,22)$. The skin must always remain clean and dry under and around the device, avoiding its insertion in areas with pre-existing skin lesions $(13,15,19,20)$.

With regard to protective dressings, transparent films or tapes should be used to allow visualization of the insertion site of the medical device as long as it is possible to apply this technology $(21,22)$. Thin hydrocolloid is indicated to avoid skin pressure and shear (25). As for the prevention of pressure, shear and moisture absorption, foam dressings are among the most indicated, as they distribute pressure better avoiding injuries (23).

Still, with regard to prevention, the use of specific materials as a preventive support of gel or cushions relieve the pressure of the device on the skin. The application of barrier cream or spray at each dressing change is essential to protect the perilesional skin or peristoma, as well as the barrier-forming tissue in the peristomal area of the tracheostomy (21).

The Nursing Diagnosis (ND) validation studies are fundamental in the search for scientific evidence and in reducing the possibility of errors in the Nursing process and in the decision making process of the nurse, emphasizing that the ND described in this Bundle are correlated with each other in the identification of MDRPI (24). The Bundle comprised three nursing diagnoses of MDRPI, which were related to Acute Pain, Impaired Skin Integrity and Pressure Injury.

Among the ND, "Acute Pain" (25) located in the region of the medical device is a diagnosis which shows the occurrence of MDRPI, since the unpleasant sensory and emotional experience associated with real or potential tissue damage, of sudden or slow onset, from light to intense intensity, with anticipated or predictable termination and lasting less than 3 months. Among the factors related to pain is the harmful physical agent (26).

Among the nursing care related to the ND of "Pain", the identification of pain located in the region of a medical device is a predictive sign of MDRPI (30). Therefore, the nurse must assess the intensity of pain using predictive scales, such as Visual Analog or Behavior Pain Scale in sedated patients using mechanical ventilation. Pain assessment in critically ill, mechanically ventilated, unconscious and sedated patients (with a level of sedation from 4 to 6 , according to the Ramsay scale) is assessed using the BPS-IP / PT scale (Behavior Pain Scale / Behavioral Scale of Brazilian version, which proved to be promising in the evaluation of pain, as they are often unable to communicate effectively, under the effect of sedation / analgesia or with a reduced level of consciousness $(27,28)$.

Regarding the ND, entitled "Impaired skin integrity" (30) defined as dermis and altered epidermis, including alteration in skin integrity, localized area hot to the touch, acute pain, foreign matter perforating the skin, redness (25). The evaluation of the skin for hyperemia around the medical device, as well as observing the insertion site to identify the occurrence of macerated tissue, in the same way that moisture, heat and the presence of edema are risk factors for MDRPI. Early detection of skin degradation is relevant to implement preventive measures and prevent the development of injuries $(13,20,23,25)$. Another relevant precaution to avoid injury to the skin is to make sure that the medical device is inserted and positioned correctly $(13,16,19)$.

It should be noted that, recently, a new ND entitled "Pressure Injury" (30) was included, which was defined by a lesion located on the skin and / or underlying tissue, usually on a bony prominence, resulting from pressure and shear or related to a device doctor or other, being categorized into stages (28). MDRPI should be classified according to the NPUAP staging system, and they are common in two stages, however, these injuries can worsen for more advanced stages if not treated $(16,29)$. The treatments of MDRPI 
constitute technological elements and systematized nursing interventions.

Among the treatments, the management of the microclimate and exudate is necessary to avoid MDRPI, so that the polyurethane foam is indicated for control and maintenance of the microclimate and moisture absorption, especially in peristomal areas (tracheostomy, colostomy, gastrostomy and other stomas), under non-invasive ventilation masks and tracheostomy cannula (23).

Regarding the application of occlusive dressings, it is important to select it according to the anatomical location, to assess how much the thickness is monolayer or multiple, avoiding overlapping of dressings (13). In relation to dressing changes, these should be carried out when there is moisture or the presence of exudate, opting for the choice of dressings that allow easy application and removal (21).

\section{Study Limitations}

Anyway, it was considered as a limitation of the study the divergence among the experts in some evaluated care and the delay in returning the instrument on the part of them, after signing the IC, was a difficulty faced in the validation steps.

\section{Contributions to the Health Area}

With regard to contributions to the area, this Bundle is considered to be extremely important for the standardization of nursing care in times of COVID19 , since, due to the severity of the clinical condition, patients make use of various medical devices predisposing the occurrence of MDRPI.

\section{Conclusions}

MDRPIs are frequent in the hospital environment, in most therapeutic treatments, it is necessary to use medical devices, predisposing the occurrence of this disease. This relationship is also present in patients who fall ill due to COVID-19, who lack critical care and are mostly elderly.

The validated items that make up the Bundle are of great relevance for the prevention, diagnosis and treatment of MDRPI and were considered valid because the general agreement of the instrument among the experts was 0.93 .

It is believed that it contributes to the systematization of nursing care and the standardization of care care, adding knowledge to nursing professionals, not only in hospitals, but also for primary health care, since we have many elderly people who they use medical devices at home, so that the importance of this care can be explained to the family / patient and caregiver.

\section{REFERENCES}

[1] World Health Organization (WHO). Rational use of personal protective equipment for coronavirus disease 2019 (COVID-19): Interim guidance. Genebra: WHO [Internet]. 2020[cited 2020 Mar 21]. Available from: https://apps.who. int/iris/bitstream/handle/10665/331498/ WHO-2019-nCoV-IPCPPE_use-2020.2-eng.pdf? sequence $=1 \&$ isAllowed $=y$

[2] Ramalho AO, Freitas PSS, Nogueira PC. Lesão por pressão relacionada a dispositivo médico nos profissionais de saúde em época de pandemia. Estima, Braz [Internet]. 2020 [cited 2020 Apr 30];18:e0120. Available from: https://www.revistaestima.com.br/index.php/estima/article/ viewFile/867/pdf_1

[3] Coronavírus: Esclarecimentos da AMIB pelo Comitê de Sepse e Infecção. AMIB - Associação de Medicina Intensiva Brasileira [Internet]. 2020 [cited 2020 Mar 21]. Available from: https:// www.amib.org.br/fileadmin/user_upload/ amib/2020/marco/21/11_CORONAVIRUS_Esclarecimentos_da_AMIB_pelo_Comite_de_ Sepse_e_Infeccao.pdf

[4] Chen N, et al. Epidemiological and clinical characteristics of 99 cases of 2019 novel coronavirus pneumonia in Wuhan, China: a descriptive study. The Lancet [Internet]. 2020 [cited 2020 Apr 30];395:507-13. Available from: https://doi. org/10.1016/S0140-6736(20)30211-7

[5] Véras JB, et al. Efeitos da posição prona em pacientes com síndrome do desconforto respiratório agudo: uma revisão sistemática. Revista Pesquisa em Fisioterapia. 2019;9(1):129-138. doi: 10.17267/2238-2704rpf.v9i1.2175v9i1.2175.

[6] European Pressure Ulcer Advisory Panel; National Pressure Injury Advisory Panel; Pan Pacific Pressure Injury Alliance. Prevention and Treatment of Pressure Ulcers/Injuries: Clinical Practice Guideline - The International Guideline. EPUAP/NPIAP/PPPIA. 2019. 
Care Bundle for Medical Device-Related Pressure Injuries in Covid-19 times

[7] Silva ATM, Mantovani MF, Godoy S, Kalinke LP, Ulbrich EM. Escala preditiva de complicações da hipertensão: validade de conteúdo e aparência. Rev Min Enferm. 2017;21:e-1007. doi: 10.5935/1415-2762.20170017

[8] Vinuto J. A amostragem em bola de neve na pesquisa qualitativa: um debate em aberto. Temáticas [Internet]. 2014 [cited 2020 Apr 2];(44): 203-220. Available from: https://econtents. bc.unicamp.br/inpec/index.php/tematicas/article/view/10977/6250

[9] Polit DF, Beck CT. Fundamentos da pesquisa em enfermagem: avaliação de evidências para a prática de enfermagem. Porto Alegre: Artmed; 2011. Prática de enfermagem baseada em evidências; p. 53-82

[10] Alexandre NMC, Coluci MZO. Content validity in the development and adaptation processes of measurement instruments. Ciênc Saúde Coletiva [Internet]. 2011 [cited 2020 Apr 25];16(7):3061-8. Available from: http://www.scielo.br/pdf/csc/ v16n7/06.pdf

[11] Wilkes L. Using the Delphi technique in nursing research. Nurs Stand. 2015; 29(39):43-49. doi: 10.7748 / ns.29.39.43.e8804.

[12] Cavalcanti EC, Kamada I. Protagonism. Lesão por pressão relacionada a dispositivo médico em adultos: revisão integrativa. Texto Contexto Enferm [Internet]. 2020 [cited 2020 Apr 20]; 29:e20180371. Available from: https://www. scielo.br/pdf/tce/v29/pt_1980-265X-tce-29e20180371.pdf

[13] European Pressure Ulcer Advisory Panel, National Pressure Ulcer Advisory Panel, Pan Pacific Pressure Injury Alliance.Prevention and Treatment of Pressure Ulcer: Quick reference guide. Cambrigde Media [Internet]. 2014 [cited 2020 Mar 20]. Available from: https://www. epuap.org/wp-content/uploads/2016/10/ quick-reference-guide-digital-npuap-epuappppia-jan2016.pdf

[14] National Pressure Ulcer Advisory Panel.Announces a change in terminology from pressure ulcer to pressure injury and updates the stages of pressure injury. National Pressure Injury Advisory Panel [Internet]. 2016. [cited 2020 Apr 20].
Available from: https://npiap.com/page/PressureInjuryStages

[15] Karadag A, Hanönü SC, Eyikara E. A Prospective, Descriptive Study to Assess Nursing Staff Perceptions of and Interventions to Prevent Medical Device-related Pressure Injury. Ostomy Wound Manage. 2017;63 (10): 34-41. doi: 10.25270 / owm.2017.10.3441.

[16] Black J, et al. Use of wound dressings to enhance the prevention of pressure ulcers caused by medical devices. International Wound Journal. 2015;12(13):322-327. doi: 10.1111/iwj.12111.

[17] Otero DP, et al. Preventing facial pressure ulcers in patients under non-invasive mechanical ventilation: a randomised control trial. Jornal of Wound Care [Internet]. 2017 [cited 2020 Mar 20];26(3). Available from: https://www. researchgate.net/publication/314485351_ Preventing_facial_pressure_ulcers_in_patients_ under_non-invasive_mechanical_ventilation_A_ randomised_control_trial

[18] Visscher MO, et al. Face masks for noninvasive ventilation: Fit, excess skin hydration, and pressure ulcers. Respiratory Care. 2015;60(11):15361547. doi: 10.4187/respcare.04036.

[19] Makic MBF. Pressure ulcers related to medical devices and intensive care patients. J Perianesth Nurs. 2015;30(4):336-337. doi: 10.1016/j. jopan.2015.05.004

[20] Kulik LA, et al. Pressure injury prevention for paediatric cardiac surgical patients using a nurse-driven standardized clinical assessment and management plan. Cardiology in the Young. 2018;28:1151-1162. doi: 10.1017/ S1047951118000975.

[21] Rathore FA, Ahmad F, Zahoor MUU. Case report of a pressure ulcer occurring over the nasal bridge due to a non-invasive ventilation facial mask. Cureus [Internet]. 2016[cited 2020 Jan 10];8(10): e813. Available from: https://www. ncbi.nlm.nih.gov/pmc/articles/PMC5094798/

[22] Zakaria AY, et al. Impact of a suggested nursing protocol on the occurrence of medical device related pressure ulcers in critically ill patients. Central European Journal of Nursing and Midwifery. 2018;9(4):924-931. doi: 10.15452/ CEJNM.2018.09.0025 
Care Bundle for Medical Device-Related Pressure Injuries in Covid-19 times

[23] Acorda DE. A Nursing and Respiratory Collaboration Prevents BiPAP-Related Pressure Ulcer. Journal Pediatric Nursing. 2015;30(4):620623. doi: 10.1016 / j.pedn.2015.04.001

[24] Santos CT, Almeida MA, Lucena AF. Diagnóstico de enfermagem risco de úlcera por pressão: validação de conteúdo. Rev. Latino-Am. Enfermagem [Internet]. 2016 [cited 2019 May 21];24:2693. Available from: https://www.scielo.br/pdf/rlae/ v24/pt_0104-1169-rlae-24-02693.pdf

[25] Herdman H, Katmitsuru S. Diagnósticos de Enfermagem da Nanda-I. Definições e Classificação 2018-2020. Tradução de Regina Machado Garcez. Porto Alegre: Artmed; 2018.

[26] Ham WH, et al. Pressure ulcers, indentation marks and pain from cervical spine immobilization with extrication collars and headblocks: An observational study. Injury [Internet]. 2016 [cited 2020 Mar 10];47(9):1924-1931. Available from: https://doi.org/10.1016/j.injury.2016.03.032
[27] Riker RR, Fugate JE. Participants in the International Multi-disciplinary Consensus Conference on Multimodality Monitoring. Clinical monitoring scales in acute brain injury: assessment of coma, pain, agitation and delirium. Neurocrit Care. 2014;21(2):27-37.doi: 10.1007/s12028014-0025-5

[28] Santos IFA, et al. Validação da versão Brasileira da Behavioral Pain Scale. Revista Brasileira de Anestesiologia [Internet]. 2017 [cited 2020 Apr 2];67(3):271-277. Availablefrom: https://reader. elsevier.com/reader/sd/pii/S01040014163003 80?token=E1AE2902EE2CADB0AB4F92E9EB77 61A382F1D4FF73EBA415F560454C5C61EF50 DA866196DC1C0A3EB514CFDE73E7D948

[29] Johnson BM, et al. Medical device-related pressure injuries: An exploratory descriptive study in an acute tertiary hospital in Australia. Journal of Tissue Viability [Internet]. 2017 [cited 2020 Jan 10];26(4):246-253. Available from: https://doi. org/10.1016/j.jtv.2017.09.008

Citation: Daniela Soldera, Bettina Heidenreich Silva, et al. Care Bundle for Medical Device-Related Pressure Injuries in Covid-19 times. Open Journal of Geriatrics. 2020; 3(2): 10-19.

Copyright: (c) 2020 Daniela Soldera, Bettina Heidenreich Silva, et al. This is an open access article distributed under the Creative Commons Attribution License, which permits unrestricted use, distribution, and reproduction in any medium, provided the original work is properly cited. 